\title{
The Use of Fish in Xenotransplantation Research
}

\author{
By Peter Alestrom
}

Norges veterinærhøgskole, Postboks 8146 Dep., N-0033 Oslo, Norway. Tel.: +47 22964571, E-post: peter.alestrom@veths.no

The development of xenotransplantation requires intelligent use of comparative biological knowledge. Even though the pig clearly stands out as the animal, which is most suited as donor of organs and tissues within human medicine, primitive vertebrates, such as fish, may contribute to research relevant to the area of xenotranplantation, and even in some cases serve as tissue donors.

As a part of molecular humanization of swine tissue, transgene-based technology has been used: Insertion mutagenesis of the $\alpha 1,3$-galactosyltransferase ( $\alpha 1,3-\mathrm{GT})$ gene after nuclear transfer and transgene- based techniques $(1,3)$. A technically safer and more refined method to obtain insertion mutagenesis is to genetically modify embryo-stem (ES) cells in culture, which subsequently are used to regenerate transgenic animals. This method has until recently exclusively been established for the mouse, but at present a sebrafish based method can also be employed for such "knockout" research (2).

One example of fish tissue that may potentially be used for xenotransplantation is "Brockmann bodies" in bonefish. These are anatomically distinct insulin producing tissue, which may easily be isolated and can be made immunologically indifferent by the use of alginate encapsulation. Work is in progress to humanize these cells by constructing transgenic tilapia enabling them to produce human insulin (4).

\section{References}

1. Dai YF, Vaught TD, Boone J, Chen SH, Phelps CJ, Ball S, Monahan JA, Jobst PM, McCreath KJ, Lamborn AE, Cowell-Lucero JL, Wells KD, Colman A, Polejaeva IA, Ayares DL: Targeted disruption of the $\alpha 1,3$-galactosyltransferase $\quad(\alpha 1,3-$ GT) gene in cloned pigs. Nature Biotechnol. 2002, 20, 251-255.

2. Fan L, Alestrom A, Alestrom P, Collodi P: Germline competent zebrafish ES cell lines. Submitted 2002.

3. Lai L, Kolber-Simonds D, Park K-W, Cheong H-T, Greenstein JL, Im G-S, Samuel M, Bonk A, Rieke A, Day BN, Murphy CN, Carter DB, Hawley RJ, Prather RS: Production of alpha-1,3-galactosyltransferase knockout pigs by nuclear transfer cloning. Science 2002, 295, 1089-1092.

4. Wright $J R J r$, Pohajdak B: Cell therapy for diabetes using piscine islet tissue. Cell Transplant. 2001, 10, 125-143. 